\title{
NEGATIVE IONS AND THEIR ROLE IN THE DEVELOPMENT OF SCIENCE AND TECHNOLOGY
}

\author{
Leonid I. Gretchikhin \\ Belarusian State Academy of Communications, \\ Minsk, Republic of Belarus, \\ e-mail: gretchihin@yandex.ru, \\ ORCID iD: (Dhttp://orcid.org/0000-0002-5358-9037
}

DOI: 10.5937/vojtehg66-17262; https://doi.org/10.5937/vojtehg66-17262

FILD: Nanotechnology

ARTICLE TYPE: Original Scientific Paper

ARTICLE LANGUAGE: English

\begin{abstract}
:
Negative ions are formed in the process of the interaction between the electron with the integrated electric dipole moment and the induced electric dipole moment due to polarization. In the continual regime, at orbital velocity, the emission of negative ions from the surface of the heatshielding coating leads to the formation of a double electric layer with a very dense plasma while at the escape velocity the same emission of negative ions creates an explosive character of burning of the heatshielding coating. In the free molecular flow regime, the emission of negative ions results in intense violet-blue glow while high positive potentials are induced on the surface of an aircraft. In nanotechnologies, the ionization of negative ions determines the parameters of vacuum arc discharge. Negative ions participate in the formation of an electrostatic machine in the human body.
\end{abstract}

Key words: negative ions, electric dipole moment, double electric layer, polarization, electrostatic machine.

\section{Introduction}

When studying the formation and destruction of negative ions, researchers have encountered a peculiar structure of negative ions. Different atoms and, especially, molecules respond to the bond with extra electrons each in its own way. This was confirmed when quantum mechanics was applied to describe the structure of the electron affinities of neutral atoms and molecules and to determine the electron affinity energies. It was found out that some atoms and molecules have greater electron affinities while the others, on the contrary, do not respond at all to the presence of free electrons in their nearest environment. For lack of 
any adequate theoretical model of the formation of negative ions, the effective use of negative ions as catalysts to achieve optimal conditions for all parameters of processes in various fields of technology is essentially limited. Therefore, it is vital to set the following goal: to consider in great detail what kinds of chemical bonds arise in the process of negative ions formation, and further, based on this knowledge, to find out the influence of negative ions on the technological processes used in the production of various machines, mechanisms, and equipment. To reach the goal, it is essential to solve the following problems:

1. To provide an explanation of the process of negative ions formation for various atomic and molecular systems.

2. To determine the role of negative ions in space exploration.

3. To consider the influence of negative ions in nanotechnologies.

4. To find out the positive role of negative ions in the human body.

Let us consider, one after another, these problems.

\section{Formation of Negative lons of Atoms and Molecules}

Theoretical calculations of electron affinity energies performed using quantum-mechanical methods did not make it possible to obtain convincing agreement with the experimental data (Massey, 1976). An especially inadequate situation relates to complex atoms and molecules. Table 1 shows particular values of electron affinities for certain atoms.

Table 1 - Parameters of Atoms of the First Group of the Periodic Table Таблица 1 - Параметры атомов первой группы таблицы Менделеева Табела 1 - Параметри атома прве групе периодног система елемената

\begin{tabular}{|l|l|l|l|l|l|}
\hline \multirow{2}{*}{ Atoms } & \multicolumn{4}{|l}{ Parameters of atoms } \\
\cline { 2 - 6 } & $r_{a}, \AA$ & $Z^{*}$ & $\begin{array}{l}p_{d} \cdot 10^{30} \\
(\mathrm{~A} \cdot \mathrm{m})\end{array}$ & $\mathrm{EA}(\mathrm{eV})$ & $\Delta r / r_{1}$ \\
\hline $\mathrm{H}$ & 0.529 & 0.500 & 0 & 0.754 & 0.0555 \\
\hline $\mathrm{Li}$ & 2.049 & 0.766 & 0 & 0.609 & 0.1130 \\
\hline $\mathrm{Na}$ & 2.227 & 0.794 & 4.34 & 0.548 & 0.1066 \\
\hline $\mathrm{Rb}$ & 2.979 & 0.864 & 11.88 & 0.486 & 0.1163 \\
\hline $\mathrm{Cu}$ & 1.762 & 0.945 & 42.45 & 1.228 & 0.1590 \\
\hline $\mathrm{Ag}$ & 1.934 & 1.017 & 38.00 & 1.302 & 0.1718 \\
\hline
\end{tabular}

Negative ions possessing a relatively high electron affinity are formed for atoms which feature a closed shell in the S-state formed 
during electron capture. As this takes place, the change in potential energy presents the electron affinity energy:

$$
E A \cong-\frac{Z^{*} e^{2}}{4 \pi \varepsilon_{0}}\left(\frac{1}{r_{2}}-\frac{1}{r_{1}}\right) \approx \frac{Z^{*} e^{2}}{4 \pi \varepsilon_{0} r_{1}} \frac{\Delta r}{r_{1}},
$$

where $Z^{*}$ is the effective nuclear charge of the neutral atom, $e$ is the electron charge, $r_{1}$ and $r_{2}$ are the distances between the atom's center and the electron of the neutral atom and between the atom's center and the electron of the negative ion, correspondingly, and $\varepsilon_{0}$ is the dielectric permittivity of vacuum.

It follows from (1) that, when the negative ion of hydrogen is formed, the relative increase in the radius of rotation of the captured electron amounts to a noticeable value: $\frac{\Delta r}{r_{1}} \approx 0.05546$ while for lithium the increase is: $\frac{\Delta r}{r_{1}} \approx 0.1130$. Table 1 presents the values of the increase for other atoms. Table 1 shows the values of the radii of neutral atoms, the effective nuclear charges of neutral atoms, and the values of the electric built-in dipole moments. It follows from the data presented in Table 1 that the deformation of the initial electron shells of neutral atoms upon capture of an electron is quite substantial. The presence of the built-in electric dipole moment of large magnitude leads to an increase in the electron affinity energy of an atom. Theoretical calculations of electron affinity energies performed using quantum-mechanical methods did not reflect in full measure the dynamics of the formation of negative ions in atomic structures. It is necessary to take into account the presence of the built-in electric dipole moment in atoms and, along with the covalent chemical bond using the Heitler-London method, other possible types of chemical bonds will be also taken into consideration. Below we show how to take into account the above conditions, following (Gretchikhin \& Kamarouskaya, 2016, pp.447-464).

\section{Formation of Negative lons in Atoms}

The paper (Gretchikhin, 2008) showed that in complex atomic systems, the deformation of spherically symmetric $s$-states occurs due to the interaction of $p-s, d-s$ or $f$-s electron shells; as a result, a built-in electric dipole moment, relative to the center of a complex atom, arises. Calculations of the built-in electric moment, taking into account Hund's 
rule, were performed for the majority of atoms in the periodic table. During the capture of a free electron by a neutral atom, there is no interaction with the positive nucleus of the atom, since the nucleus of the atom is completely screened by the electrons around the atom. However, as the free electron approaches the atom, its electric field polarizes the atomic system. In this case, the interaction with the displaced cloud of all electrons of the neutral atom arising due to polarization takes place, but not with the effective charge of the nucleus.

In the presence of the built-in electric dipole moment in the atom, the interaction between an external free electron and the electric dipole is activated. In this situation, the atom is able to gain an electron and to become a negative ion. Under the action of the electric field of this electron, the displacement of the electron cloud of the neutral atom relative to its center occurs in all energy states. If the external field is created by an external electron, then the condition of equilibrium of forces for the electron inside the atom in $k$-th state is as follows:

$$
\frac{e^{2}}{4 \pi \varepsilon_{0} r_{0}^{2}}=\frac{Z_{k}^{*} e^{2}}{4 \pi \varepsilon_{0} r_{k}^{2}}-\frac{Z_{k}^{*} e^{2}}{4 \pi \varepsilon_{0}\left(r_{k}+\Delta r_{k}\right)^{2}} .
$$

where $r_{k}$ is the radius of electron rotation of the atom in the $k$-state, $Z_{k}^{*}$ is the effective nuclear charge of the atom in the $k$-th state for the electron under consideration, and $r_{0}$ is the radial distance of the negative ion from the atom center.

Hence, the displacement of the outer electron cloud of the $k$-th energy state relative to the atom's center is as follows:

$$
\Delta r_{k} \approx \frac{r_{k}^{3}}{2 Z_{k}^{*} r_{0}^{2}} \text {. }
$$

The energy of the interaction of the outer electron with the built-in electric dipole of the atom with taking into account the energy for polarization represents the electron affinity and is expressed as follows:

$$
E A \cong-\frac{2 e p_{d}}{4 \pi \varepsilon_{0} r_{0}^{2}}+\sum_{k} \frac{Z_{k}^{*} e^{2}}{4 \pi \varepsilon_{0}}\left[\frac{1}{r_{0}}-\frac{1}{r_{0}+\Delta r_{k}}\right] \text {. }
$$

Here, $p_{d}$ is the built-in electric dipole moment of the neutral atom. It is obvious that the potential of the interaction between the electron and the neutral atom will be minimal. Otherwise, the system will not be stable. That is the reason why the electron affinity and the negative ion radius are determined by the minimum value of the interaction potential (4). The results of the interaction potential calculations for the atoms of carbon, 
oxygen, copper and titanium have been performed in (Gretchikhin \& Kamarouskaya, 2016, pp.447-464).

Electron affinity energy can be measured with high accuracy, i.e. with an accuracy within $3 \%$. Therefore, using the values of electron affinity of an atom makes it possible to obtain real values of built-in electric dipole moments of complex atomic systems and, at the same time, the negative ion radius.

The electron affinity of the carbon atom for the atom's radius $r_{a}=$ $1,091 \AA$, the distance of the valence electron of the negative ion from the atom's center $r_{0}=1,095 \AA$ and $p_{d}=3,935 \cdot 10^{-30} \mathrm{C} \cdot \mathrm{m}$, equals to the experimental value of $1.263 \mathrm{eV}$. The radius of the carbon atom is slightly bigger than the value obtained using the quantum-mechanical method: $0.905 \AA$ (Brattsev, 1966) and 0.922 (Radzig \& Smirnov, 1985). For atom's radius of $0.905 \AA$ the experimental value of the electron affinity is realized in the negative ion at the distance from the atom's center of 1.02 $\AA$ and for the built-in electric dipole moment $p_{d}=3,089 \cdot 10^{-30} \mathrm{C} \cdot \mathrm{m}$.

For the oxygen atom with the value of the built-in electric dipole moment $p_{d, O}=2,891 \cdot 10^{-30} \mathrm{C} \cdot \mathrm{m}$, the atom's radius of $0.7073 \AA$ and the negative ion's radius $r_{0}=1,04 \AA$ the electron affinity energy equals $1.4611 \mathrm{eV}$, the value which corresponds to the measured one.

Therefore, electron affinity of atoms is determined by the interaction of the outer electron with the built-in electrical moment of the complex atomic system as well as by coulombic interactions of the electrons of negative ions with the electrons of the neutral atom of all energy states and atom nuclei.

\section{Negative lons of Diatomic Molecules}

Electric dipole moments in diatomic molecules are oriented opposite to each other. It follows from the composition of diatomic molecules that they can gain two electrons and become a doubly charged negative ion. Electron affinity energy for a singly charged negative ion is as follows:

$$
\begin{gathered}
E A_{m} \cong-\frac{2 e p_{d, 1}}{4 \pi \varepsilon_{0} r_{1}^{2}}+\frac{2 e p_{d, 2}}{4 \pi \varepsilon_{0} r_{2}^{2}}+\frac{e \Delta Q}{4 \pi \varepsilon_{0} r_{m}}+\sum_{k} \frac{Z_{k}^{*} e^{2}}{4 \pi \varepsilon_{0}}\left[\frac{1}{r_{1}+r_{n}}-\frac{1}{r_{1}+r_{n}+\Delta r_{k}}\right] . \\
\text { Here, } \Delta r_{k}=\frac{r_{e f f}^{3}}{2 Z_{k}^{*} r_{1}^{2}} \text { and it determines the displacement of the }
\end{gathered}
$$
valence electron cloud in the molecule; $Z_{k}^{*}$ is the effective molecular 
charge in the $k$-state; $r_{\text {eff }}$ is the effective molecular radius; $r_{1}$ is the distance to the center of the nearest atom determined by the position of the interaction potential minimum; $r_{m}$ is the distance to the molecule center, $r_{n}$ is the additional distance to the next atom, equal to $r_{e}, p_{d, 1}$ and $p_{d, 2}$ are the built-in electric dipole moments of the ions of the interacting atoms, correspondingly; and $\Delta Q$ is the induced charge occurring as a result of the valence electrons exchange at the covalent bound in the diatomic molecule.

The sum in the potential (5) considers the energy input for the polarization of the valence electron cloud of the diatomic molecule and for the polarization of the electron cloud of the positive core atoms. In particular, the theoretical calculation of the electron affinity value using (5) for the carbon molecule for the effective radius of the interacting atoms of $0.905 \AA$ (Radzig \& Smirnov, 1985) and for the electric dipole moment of a singly charged negative ion of the atom of the molecule positive core $p_{d, i}=1,976 \cdot 10^{-30} \mathrm{C} \cdot \mathrm{m}$ amounts to the experimentally obtained value of $3,39 \mathrm{eV}$ for the distance from the nearest atom of $0.7643 \AA$, i.e. the distance to which the electron approaches the atom center in the diatomic molecule.

\section{Electron Affinity of Triatomic Molecules}

A triatomic molecule is formed as a result of the atom interaction with a diatomic molecule. During this process, the common electron shell is formed by all three valence electrons of complex atoms. That is the reason why the positive core of the triatomic molecule contains singly charged positive ions of the initial atoms. The built-in electric dipole moments of the single ions are arranged so as to maximally increase the bond energy between the atom and the diatomic molecule.

At the same time, the distance between the atoms corresponds to a bit bigger interval than the equilibrium distance between the atoms in the diatomic molecule. The nearest atom in the diatomic molecule is considered as the central one.

The distances of the atoms from the central atom are approximately equal; it is designated as $r_{\mathrm{e}}$. Other distances expressed in terms of $r_{\mathrm{e}}$ are as follows:

$$
r_{1}=2 r_{e} \sin (\alpha / 2) ; r_{2}=r_{e} \sqrt{1,25-\cos \alpha} ; r_{3}=r_{e} \sin (\alpha / 2),
$$

where $\alpha$ is the central angle in the triatomic molecule. 
The triatomic molecule captures the electron to its outer orbit. The electron affinity of a triatomic molecule is determined by the interaction with the integrated dipole moments of all three ions of the positive core and by its polarization. The distance of the captured electron from the molecule's center does not exceed the molecule's effective radius. The electron affinity energy of the positive core of the triatomic molecule is mainly determined by the interaction between the valence electron and the built-in electric dipole moment of the nearest ion. The distance to which the electron approaches the nearest ion of the atomic core does not exceed the radius of the triply charged ion of the molecule. The resultant binding energy of the valence electron of the negative ion of the triatomic molecule equals to:

$$
E A_{1}=-E_{1}+E_{2}+E_{3}+E_{4}-E_{5}+E_{6},
$$

where $E_{1}=\frac{2 e p_{d}}{4 \pi \varepsilon_{0} r^{2}} ; E_{2}=\frac{e \Delta Q}{4 \pi \varepsilon_{0}\left(r+r_{e} / 2\right)} ; E_{3}=\frac{e \Delta q}{4 \pi \varepsilon_{0}\left(r+r_{2}\right)}$;

$E_{4}=\frac{2 \cos (\pi-\alpha) e p_{d}}{4 \pi \varepsilon_{0}\left(r+r_{e}\right)^{2}} ; E_{5}=\frac{2 e p_{d} \cos \left(\frac{\pi-\alpha}{2}\right)}{4 \pi \varepsilon_{0}\left(r+r_{1}\right)^{2}} ;$

$E_{6}=\sum_{k} \frac{Z_{k}^{*} e^{2}}{4 \pi \varepsilon_{0}}\left(\frac{1}{r+r_{2} / 2}-\frac{1}{r+r_{2} / 2+\Delta r_{k}}\right)$

and $\Delta r_{k}=\frac{r_{\text {eff }}^{3}}{2 Z_{k}^{*}\left(r+r_{2} / 2\right)^{2}}$.

Here, $\Delta Q$ and $\Delta q$ are the charges induced inside the diatomic molecule and between the outer atoms and the diatomic molecule, correspondingly, determined using the Heitler-London method.

When the triatomic molecule becomes a doubly charged negative ion, the bound energy of the second electron weakens and can be determined using the following formula

$$
E A_{2}=E A_{1}+\frac{e^{2}}{4 \pi \varepsilon_{0} 3 r_{a}} \text {. }
$$

The following results have been obtained:

1. When considering the electron affinity of an atom, the interaction of an electron with the built-in electric dipole moment of a neutral atom and the repulsive forces between the valence electrons of neutral atoms and a negative ion in accordance with Coulomb's law will be considered. 
2. The electron affinity of a diatomic molecule is determined by the electron interaction with two built-in electric dipole moments of the atomic ion, the induced negative cloud at the boundary of the atoms within the molecule, as well as by the Coulomb's interactions of the valence electrons of the negative ion and those of the neutral molecule.

3 . In the process of electron capture by a triatomic molecule, the electron affinity energy is determined by the interaction of an electron with the built-in electric dipole moments of all three ions forming the positive core of the molecule as well as by the Coulomb's interactions of the outer electron of the triatomic molecule and the induced charges.

Negative ions play a special role in various fields of engineering and human activity. During the exploration of outer space, the researchers encountered the formation and ionization of negative ions. In nanotechnologies, negative ions make it possible to improve both the technologies of nanomaterials manufacture and the physical properties of materials. As for the influence of negative ions on the functions of the human body, their impact is invaluable.

\section{Negative lons in Space Exploration}

As rocket technologies were developed, it became necessary to find out what processes of interaction with the environment accompany the rocket flights into space. The first studies in this domain were performed during the flights of a geophysical rocket along a ballistic trajectory in the 50 s of the last century (Johnson \& Heppner, 2012, pp.575-575). The results showed that only negative ions with masses of $46,32,29,22,16$ or, expressed in percentage, $96.5 ; 1.6 ; 0.2 ; 1.0 ; 0.7$ were present at the surface of the rocket at the altitude of $131 \mathrm{~km}$. Positive ions $N_{2}^{+}$were present in the illuminated zone. lons with mass numbers of 46, 32 and 16 are identified as $\mathrm{NO}_{2}^{-}, \mathrm{O}_{2}^{-}$, and $\mathrm{O}^{-}$. Mass numbers 29 and 22 correspond to the products of gasification of the rocket surface. These can be molecules $\mathrm{COH}^{-}$and $\mathrm{Na}^{-}$. The presence of negative ions at the rocket surface indicates an intense surface catalysis with the formation of negative ions. These results served as an impetus for intensive studies of negative ions formation during flights of rockets and spacecraft.

The first problem researchers faced was interrupted radio communication occurring at flight altitudes from 80 to $20 \mathrm{~km}$ due to the formation of a very dense plasma around the descent vehicle. However, formation of shock waves does not create any dense plasma. Then the researchers paid their attention to the process of burning of the heat- 
shielding coating. Under these conditions, the combustion products contain molecule $C_{3}$, which has the electron affinity energy of $2.5 \mathrm{eV}$.

For this reason, the molecule leaves the surface of the heat-shielding coating in the form of a negative ion. Plasma parameters within the double electric layer correspond to those of arc discharge. At the moment of the communication session, the coolant was injected into the forward hemisphere and the communication was restored.

When space vehicles enter the dense layers of the atmosphere at the escape velocity, the heat-shielding coating should burn more intensively. The engineers faced the problem: how to save the descent vehicle. The temperature of the shock wave is quite high. Intensive convective heat exchange is realized; this fact allowed to find out the depth of the heat-shielding coating which should burn out. It turned out the depth amounted to $\sim 2 \mathrm{~m}$. The result was shocking. Negative ions came to the rescue. Ionization of negative ions creates an intense flow of electrons at the surface of the heat-shielding coating and together with radiant and convective heat flows makes the resultant flow so high that the skin layer explodes and heat ceases to arrive onto the surface of the spacecraft. Particular assessments showed that the heat-shielding coating should burn less at the escape velocity than at the orbital velocity. The descent vehicle of the spacecraft which circled the Moon, after having descended at the escape velocity, had the depth of burnt out heat-shielding coating of $\sim 2 \mathrm{~cm}$ while the depth of burnt out heatshielding coating of the vehicles descending at the orbital velocity amounted to $\sim 3 \mathrm{~cm}$. Combustion of the heat-shielding material at the escape velocity occurs not continuously but with separate explosive pulses.

Artificial Earth satellites (AES) flying at high altitudes are under the conditions of the free molecular flow regime. Atoms and molecules of the environment bombard the surface of the aircraft. At high altitudes in the Earth's atmosphere, oxygen atoms are present in a rather large amount. Due to high physical adhesion, oxygen atoms envelop the surface of the aircraft and create an oxygen film. Under the action of the incident flow, the atoms of the incident flow are exchanged with the oxygen atoms which leave the surface of the aircraft in the form of negative ions. As a result, the surface of the aircraft is charged positively. The induced potential on the surface of an aircraft flying at altitudes above $1000 \mathrm{~km}$ can reach $\sim 1.5 \mathrm{kV}$. This potential, acting through a common wire, makes all electronic equipment of the satellite inoperative. This phenomenon was encountered during the first flights of artificial Earth satellites. Now it 
is all in the past, but in the initial period of space exploration it was not clear why satellites at high altitudes suddenly fail.

A special situation arose around the "Gretchikhin Effect" (Gretchikhin, 2003, pp.31-33) (Gretchikhin, 1985) in 1969 based on the emission of negative oxygen ions and the formation of a double electric layer, the phenomenon of intense violet-blue glow around the front hemisphere of an AES flying at the altitudes of up to $500 \mathrm{~km}$, with the maximum glowing occurring at the altitude of $110-140 \mathrm{~km}$, mainly in the shadow zone of the Earth, was predicted. In 1971, during the emergency descent of the Soyuz-10 ship the cosmonauts visually observed this glow in the shadow zone of the Earth.

Based on theoretical calculations of the thickness of the double electric layer at different altitudes, the electron concentration and the energy distribution function, the nonequilibrium radiation of this layer was calculated in different spectral lines and molecular bands of nitrogen and oxygen. Figure 1 shows the results of the calculations for the ball of radius $1 \mathrm{~m}$ moving at a speed of $7.5 \mathrm{~km} / \mathrm{s}$. The glow of the double electrical layer at flight altitudes below $180 \mathrm{~km}$ is much greater than day airglow and even polar lights. At the flight altitude of $\sim 120 \mathrm{~km}$, the nonequilibrium glow is comparable to the magnitude of solar radiation within the range of $400-500 \mathrm{~nm}\left(\sim 9.6 \mathrm{~W} / \mathrm{m}^{2} \mathrm{sr}\right)$. The glow varies according to the cosine law depending on the angle of attack. The maximum energy value of the nonequilibrium glow corresponds to the flight altitude of $\sim 110 \mathrm{~km}$ both in the shadow zone of the Earth and in the illuminated zone. In the shadow zone of the Earth, the Meinel bands and the bands of the first negative system of hydrogen give a clearly pronounced maximum at the altitude of $120 \ldots 140 \mathrm{~km}$ and have maximum energy of radiation.

In accordance with the predictions of the theory, the measurements were carried out on-board of the long-term space station Salyut-4 with specially designed SFM/M photometric equipment. At the flight altitude of $350 \mathrm{~km}$, there was detected a luminescence corresponding in brightness to that of the theoretical calculations in the spectral lines of oxygen, nitrogen, and in the molecular nitrogen band. A cosine distribution of the luminescence along the angle of attack was obtained, as predicted by the theory.

Similar results were obtained in the U.S.A. during STS-41 and Spacelab-1 missions (Mahon et al, 1983) ten years later. The results of these measurements are also shown in Fig. 1. The explanation of the observed frontal glow by chemiluminescence (Prince, 1985, pp.453-456) (Engebretson \& Hedin, 1986, pp.109-112) or by the discharge model of 
Papadopoulos (Papadopoulos, 1983, pp.227-244) does not stand up to scrutiny.

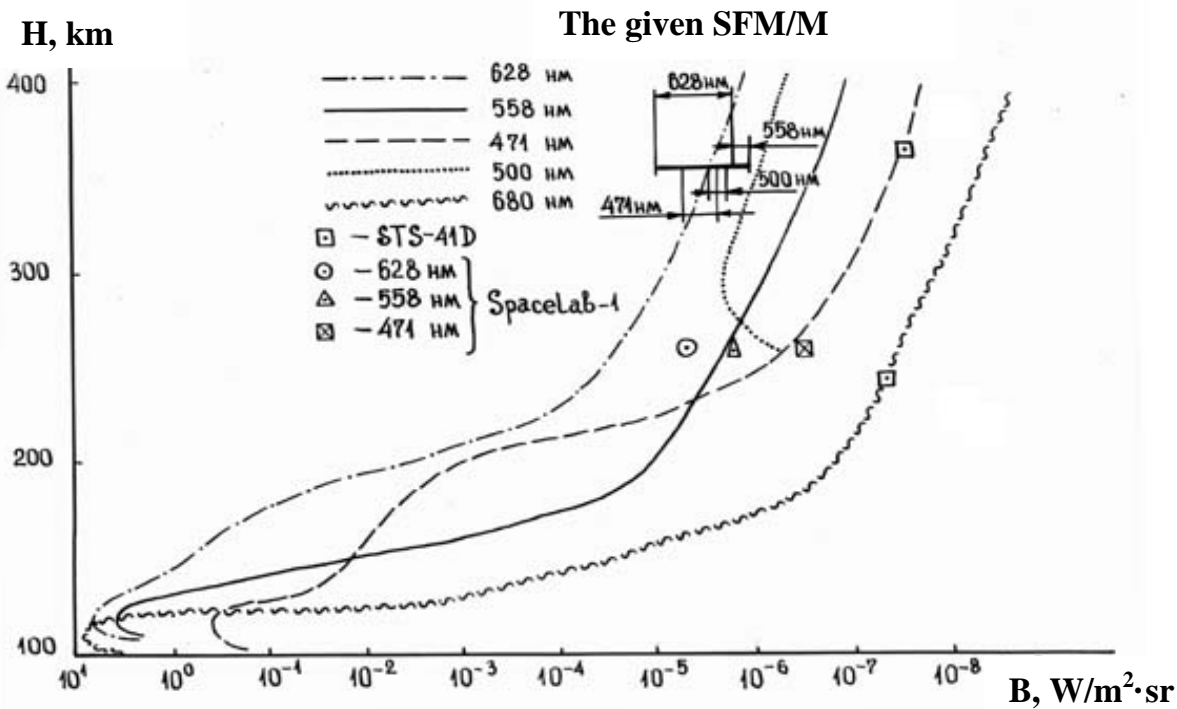

Figure 1 - Calculations of altitude curves of the non-equilibrium glow brightness in comparison to the experimental data

Pис. 1 - Расчет высотного хода яркости неравновесного свечения по сравнению с экспериментальными данными

Слика 1 - Израчунавање кривих јачине неравнотежног сјаја у односу на надморску висину у поређењу с експерименталним подацима

It is necessary to note one more phenomenon caused by the interaction of a solid body with the particles of near-Earth space with the participation of negative ions. Under the conditions of dynamic equilibrium, the flow of electrons in the environment is partially compensated by the flow of negative ions that escape into the surrounding space. Due to the chemical reactions of ionization of negative ions, epithermal electrons with energies in the range $0.4 \ldots 3.6$ $\mathrm{eV}$ are produced. These electrons lead to the effective excitation of the energy levels of atoms and molecules, whose spontaneous emission for forbidden oxygen lines is significantly delayed. Therefore, at a certain distance from the spacecraft, there should appear a pink-red halo and the spacecraft trail must also have the same color. The pink-red halo was actually detected with the maximum at the distance of $\sim 1 \mathrm{M}$ from the ship (Papadopoulos, 1983, pp.227-244). 
Thus, the theoretical model of the interaction of a solid body with near-earth space, in comparison to the experimental data, has been fully confirmed according to the following parameters and functions under investigation: radiation energy, spectral composition, dependences on oxygen concentrations in the environment, altitude curves of nonequilibrium glow brightness, brightness distribution around the aircraft, influence of the surface on the magnitude of radiation brightness, energy distribution of electrons, and the direct proof of the presence of negative ions near the aircraft surfaces.

\section{Negative lons in Nanotechnologies}

Modern microelectronics engineering is developing using nanotechnologies. The negative ions play a decisive role in these technologies (Gretchikhin, 2018, pp.304-321). To form $p$ - or $n$ conductivity, boron or arsenic which possess the ionization energies of $8.3 \mathrm{eV}$ and $9.82 \mathrm{eV}$, accordingly, are applied onto the surface of a silicon crystal. The ionization energies of neutral boron and arsenic are located in the vicinity of the electron density distribution maximum of the first Brillouin zone of the silicon crystal. Since the atoms of boron and arsenic possess electron affinity energy, they freely capture electrons from the first Brillouin zone and are turned into negative ions with further transition to the band gap of the silicon crystal. The contact potential difference of two silicon crystals with introduced boron and arsenic is $0.5 \mathrm{~V}$. The difference in the electron affinity energies corresponding to the $p-n$ junction amounts to $0.5 \mathrm{~V}$ and agrees with the experimentally measured value.

When applying hardening coatings of nano-sized thicknesses, highcurrent arc discharges are used. When applying TiN coatings, two arc discharges with the electrodes made of titanium and copper are used to achieve more effective ionization. The electron affinity of the copper atom is $1.23 \mathrm{eV}$. The average effective temperature of electrons resulting from the ionization of negative ions of copper atoms by electron impact is $7850 \mathrm{~K}$. The experimental measurements of plasma temperature by the spectroscopic method in an arc discharge between copper electrodes and under the action of laser radiation on a copper plate yielded a result of $7900 \mathrm{~K}$ (Gretchikhin \& Minko, 1967). 
For more than a century, it has been known that cathode flames in the tangential magnetic field are not deflected in accordance with Ampere's law. This phenomenon occurs as a result of negative ions ionization within the flame of the cathode spot when a reverse current, by an order greater than the charge current, is realized (Gretchikhin et al, 2016, pp.670-689). This experiment should be considered as an experimental proof of the pulse impact of the intense heat flow on the heat-shielding coating when a spacecraft re-enters the Earth's atmosphere at the escape velocity.

\section{Negative lons in the Human Body}

The human body presents a complex electrostatic machine. Little attention is paid to this fact. In this aspect, negative ions play both a negative and a positive role. Human blood carries a positive charge formed mainly by twice ionized calcium and singly ionized potassium. The negative charge on the skin surface, amounting from 6 to $12 \mathrm{~V}$, completely neutralizes the positive charge carried by blood. Blood performs a transport function, that is, delivers nutrients and takes away metabolic waste products. This is its main role. For blood to fulfill this role, it is necessary to ensure its circulation. The circulation of blood is ensured by the heart, which responds to the positive charge carried by blood, by means of pulse contractions.

Most metabolic waste products have electron affinity. As a consequence, the magnitude of the positive blood charge. As the metabolic rate in the body increases, the positive charge decreases noticeably. The spleen, together with the liver, clears blood from metabolic products, and outputs the negative charge onto the skin surface. When the complete purification of blood from metabolic products takes place, the body functions normally. The positive charge in blood is high enough to cause the contractions of the heart muscles. Otherwise, heart failure occurs which can lead to death. When intravenous laser irradiation of blood is used the negative ions are ionized. As a result, electrons are spontaneously released onto the surface, and functions of the spleen and liver are improved sharply; they now can solve their main task: to remove metabolic products from the body.

\section{Conclusions}

Based on the performed analysis of the formation and the action of negative ions under different conditions, the obtained results can be summarized as follows: 
1. The electron affinity of negative ions is determined by the interaction of the electron with the built-in electric dipole moment and the induced electric dipole moment due to the polarization.

2. Under the conditions of continual flow over the frontal surface of the descent vehicles of the artificial Earth satellites at the orbital velocity, the emission of negative ions results in a double electric layer with the parameters of arc discharge plasma.

3. Under the conditions of continual flow over the frontal surface of the descent vehicles of the artificial Earth satellites at the escape velocity, the emission of negative ions and their ionization creates an explosive character of burning of the heat-shielding coating.

4. In the free molecular flow regime, intense emission of negative ions and their ionization by means of electron impact results in the formation of a double electric layer with non-equilibrium plasma which occurs under the conditions of glow discharge.

5. Nanotechnologies use arc discharges under reduced pressure with high electric currents, where plasma is determined by the ionization of negative ions, which creates back currents, exceeding the main discharge current in the cathode spots.

6 . In the human body, negative ions have a beneficial effect on the blood for transporting nutrients and play a negative role when metabolic waste products produce negative ions in blood thus reducing its positive charge necessary for heart functioning.

\section{References}

Brattsev, V.F. 1966. Tablicy atomnyh volnovyh funkcij. Mocsow-Leningrad: Nauka (in Russian). (In the original: Братцев, В.Ф. 1996. Таблицы атомных волновых функций. - М.-Л.: Изд. «Наука». 1966).

Engebretson, M.J., \& Hedin, A.E. 2012. DE-2 mass spectrometer observations relevant to the shuttle glow. Geophysical Research Letters, 13(2), pp.109-112. Available at: https://doi.org/10.1029/gl013i002p00109.

Gretchikhin, L.I. 1985. Neravnovesnoe opticheskoe izluchenie vozdushnyh i kosmicheskih letatel'nyh apparatov. Minsk: Belarusian Polytechnic Institute. Ph.D. thesis (in Russian). (In the original: Гречихин, Л.И. 1985. Неравновесное оптическое излучение воздушных и космических летательных аппаратов. Минск: Белорусский политехнический институт. Докторская диссертация). 
Gretchikhin, L.I. 2003. Vzaimodejstvie tverdogo tela s okruzhajushhej sredoj v rezhime svobodnomolekuljarnogo obtekanija (jeffekt Gretchikhina). In The First Belarusian Space Congress, Minsk, pp.31-33. October 28-30 (in Russian). (In the original: Гречихин, Л.И. 2003. Взаимодействие твердого тела с окружающей средой в режиме свободномолекулярного обтекания (эфффект Гречихина). В Первый Белорусский космический конгресс, г. Минск, с.31-33. 28-30 октября).

Gretchikhin, L.I. 2008. Nanochasticy $i$ nanotehnologii. Minsk: Pravo i ekonomika (in Russian). (In the original: Гречихин, Л.И. 2008. Наночастицы и нанотехнологии. Мн.: Право и экономика).

Gretchikhin, L.I. 2018. Formation of p-, n-conductivity in semiconductors. Vojnotehnički glasnik/Military Technical Courier, 66(2), pp.304321. Available at: https://doi.org/10.5937/vojtehg66-15935.

Gretchikhin, L.I., \& Kamarouskaya, V.M. 2016. Negative ions of atoms and diatomic and triatomic molecules. Vojnotehnički glasnik/Military Technical Courier, 64(2), pp.447-464. Available at: https://doi.org/10.5937/vojtehg64-9685.

Gretchikhin, L.I, Latushkina, S.D., \& Kamarouskaya, V.M. 2016. Double electrical layer in the cathode spot. Vojnotehnički glasnik/Military Technical Courier, 64(3), pp.670-689. Available at: https://doi.org/10.5937/vojtehg64-9851.

Gretchikhin, L.I., \& Minko, L.Y. 1967. Ob analogii fizicheskih processov protekajushhih $\mathrm{v}$ impul'snom razrjade i pri vozdejstvii koncentrirovannogo lazernogo izluchenija. Zhurnal tehnicheskoj fiziki, 37 (in Russian). (In the original: Гречихин, Л.И., Минько, Л.Я. 1967. Об аналогии фризических процессов протекающих в импульсном разряде и при воздействии концентрированного лазерного излучения. Журнал технической фризики, 37).

Radzig, A.A., \& Smirnov, B.M. 1985. Reference Data on Atoms, Molecules, and lons. Berlin: Springer-Verlag.

Johnson, C.Y., \& Heppner, J.P. 2012. Daytime measurement of positive and negative ion composition to $131 \mathrm{~km}$ by rocket-borne spectrometer. Journal of Geophysical Research,61(3), pp.575-575. Available at: https://doi.org/10.1029/jz061i003p00575.

Mahon, W., Salter, R., Hills, R., \& Delorey, D. 1983. Measured electron contribution to shuttle plasma environment, paper presented at Shuttle Environment and Operations Meeting, AIAA Paper No. AIAA-83-2598, Washington, D.C.

Massey, H. 1976. Negative ions. Cambridge University Press.

Papadopoulos, K. 1983. The Space Shuttle environment as evidence of critical inization phenomena. In Active Exp. Space. Proc. Int. Symp., Alpbach, Paris, pp.227-244. May 24-28.

Prince, R.H. 2012. On spacecraft-induced optical emission: A proposed second surface luminescent continuum component. Geophysical Research Letters, 12(7), $\quad$ pp.453-456. https://doi.org/10.1029/gl012i007p00453.

Available

at: 


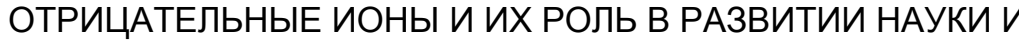 ТЕХНОЛОГИИ}

Леонид И. Гречихин

Белорусская государственная академия связи,

г. Минск, Республика Беларусь

ОБЛАСТЬ: нанотехнологии

ВИД СТАТЬИ: оригинальная научная статья

ЯЗЫК СТАТЬИ: английский

Резюме:

Отрицательные ионы образуются при взаимодействии электрона со встроенным дипольным электрическим моментом $u$ наведенным дипольным электрическим моментом вследствие поляризации. В континуальном режиме при первой космической скорости эмиссия отрицательных ионов с поверхности теплозащитного покрытия приводит к формированию двойного электрического слоя с очень плотной плазмой, а при второй космической скорости эта же эмиссия отрицательных ионов создает взрывной характер горения теплозащитного покрытия. При свободномолекулярном режиме обтекания эмиссия отрицательных ионов приводит к возникновению мощного фриолетово-голубого свечения, а на поверхности летательного аппарата наводятся большие положительные потенциалы. В нанотехнологиях ионизация отрицательных ионов определяет параметры вакуумного дугового разряда. Отрицательные ионы участвуют в фрормировании электростатической машины в человеческом организме.

Ключевые слова: отрицательные ионы, дипольный электрический момент, двойной электрический слой, поляризация, электростатическая машина.

НЕГАТИВНИ ЈОНИ И ЊИХОВА УЛОГА У РАЗВОЈУ НАУКЕ И ТЕХНОЛОГИЈЕ

Леонид И. Гречихин

Белоруска државна академија за саобраћај и везе,

Минск, Република Белорусија

ОБЛАСТ: нанотехнологије

ВРСТА ЧЛАНКА: оригинални научни чланак

ЈЕЗИК ЧЛАНКА: енгЛескИ

Сажетак:

Негативни јони се формирају у процесу интеракције између електрона с интегрисаним електричним диполним моментом и 
индукованим електричним диполним моментом услед поларизације. У континуалном режиму, при орбиталној брзини, емисија негативних јона с површине топлотно-заштитног слоја доводи до формирања двоструког електричног слоја с веома густом плазмом, док при брзини ослобађања иста емисија негативних јона доводи до експлозивног сагоревања топлотнозаштитног слоја. У режиму слободног тока молекула емисија негативних јона резултира интензивним љубичастоплавим сјајем, док се на површини летелице ствара висок позитивни потенцијал. У нанотехнологијама јонизација негативних јона одређује параметре отпуштања вакуумског лука. Негативни јони учествују у формирању неке врсте електростатичке машине у људском телу.

Кључне речи: негативни јони, електрични диполни моменат, двоструки електрични слој, поларизација, електростатичка машина.

Paper received on / Дата получения работы / Датум пријема чланка: 24.04.2018. Manuscript corrections submitted on / Дата получения исправленной версии работы / Датум достављања исправки рукописа: 02.07.2018.

Paper accepted for publishing on / Дата окончательного согласования работы / Датум коначног прихватања чланка за објављивање: 04.07.2018.

(C) 2018 The Author. Published by Vojnotehnički glasnik / Military Technical Courier

(www.vtg.mod.gov.rs, втг.мо.упр.срб). This article is an open access article distributed under the terms and conditions of the Creative Commons Attribution license (http://creativecommons.org/licenses/by/3.0/rs/).

(ㄷ 2018 Автор. Опубликовано в «Военно-технический вестник / Vojnotehnički glasnik / Military Technical Courier» (www.vtg.mod.gov.rs, втг.мо.упр.срб). Данная статья в открытом доступе и распространяется в соответствии с лицензией «Creative Commons» (http://creativecommons.org/licenses/by/3.0/rs/).

( 2018 Аутор. Објавио Војнотехнички гласник / Vojnotehnički glasnik / Military Technical Courier (www.vtg.mod.gov.rs, втг.мо.упр.срб). Ово је чланак отвореног приступа и дистрибуира се у складу са Creative Commons licencom (http://creativecommons.org/licenses/by/3.0/rs/).

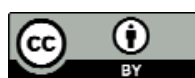

